\title{
Note : measuring breakdown characteristics during the hot re- ignition of high intensity discharge lamps using high frequency alternating current voltage
}

Citation for published version (APA):

van den Bos, R. A. J. M., Sobota, A., Manders, F., \& Kroesen, G. M. W. (2013). Note : measuring breakdown characteristics during the hot re-ignition of high intensity discharge lamps using high frequency alternating current voltage. Review of Scientific Instruments, 84, 046103-1/3. [046103]. https://doi.org/10.1063/1.4801850

DOI:

$10.1063 / 1.4801850$

Document status and date:

Published: 01/01/2013

Document Version:

Publisher's PDF, also known as Version of Record (includes final page, issue and volume numbers)

\section{Please check the document version of this publication:}

- A submitted manuscript is the version of the article upon submission and before peer-review. There can be important differences between the submitted version and the official published version of record. People interested in the research are advised to contact the author for the final version of the publication, or visit the $\mathrm{DOI}$ to the publisher's website.

- The final author version and the galley proof are versions of the publication after peer review.

- The final published version features the final layout of the paper including the volume, issue and page numbers.

Link to publication

\footnotetext{
General rights

- You may freely distribute the URL identifying the publication in the public portal. follow below link for the End User Agreement:

www.tue.nl/taverne

Take down policy

If you believe that this document breaches copyright please contact us at:

openaccess@tue.nl

providing details and we will investigate your claim.
}

Copyright and moral rights for the publications made accessible in the public portal are retained by the authors and/or other copyright owners and it is a condition of accessing publications that users recognise and abide by the legal requirements associated with these rights.

- Users may download and print one copy of any publication from the public portal for the purpose of private study or research.

- You may not further distribute the material or use it for any profit-making activity or commercial gain

If the publication is distributed under the terms of Article $25 \mathrm{fa}$ of the Dutch Copyright Act, indicated by the "Taverne" license above, please 


\section{AIP}

Note: Measuring breakdown characteristics during the hot re-ignition of high intensity discharge lamps using high frequency alternating current voltage

R. A. J. M. van den Bos, A. Sobota, F. Manders, and G. M. W. Kroesen

Citation: Rev. Sci. Instrum. 84, 046103 (2013); doi: 10.1063/1.4801850

View online: http://dx.doi.org/10.1063/1.4801850

View Table of Contents: http://rsi.aip.org/resource/1/RSINAK/v84/i4

Published by the American Institute of Physics.

Additional information on Rev. Sci. Instrum.

Journal Homepage: http://rsi.aip.org

Journal Information: http://rsi.aip.org/about/about_the_journal

Top downloads: http://rsi.aip.org/features/most_downloaded

Information for Authors: http://rsi.aip.org/authors

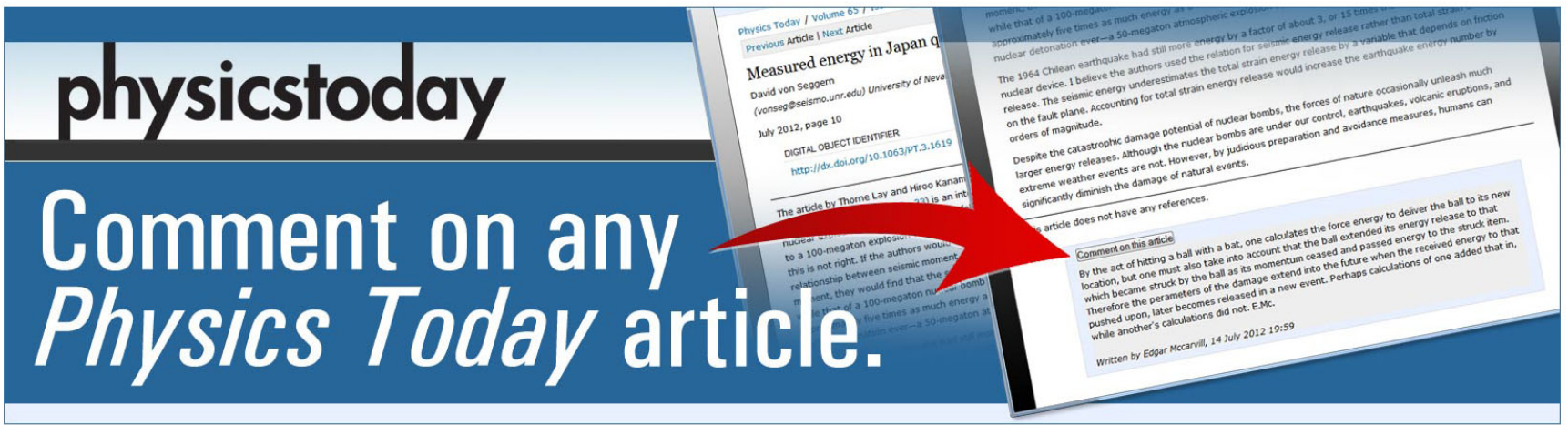




\title{
Note: Measuring breakdown characteristics during the hot re-ignition of high intensity discharge lamps using high frequency alternating current voltage
}

\author{
R. A. J. M. van den Bos, ${ }^{1}$ A. Sobota, ${ }^{1, \text { a) }}$ F. Manders,${ }^{2}$ and G. M. W. Kroesen ${ }^{1}$ \\ ${ }^{1}$ Department of Applied Physics, Eindhoven University of Technology, PO Box 513, \\ 5600 MB Eindhoven, The Netherlands \\ ${ }^{2}$ Philips Innovative Applications, Steenweg op Gierle 417, B-2300 Turnhout, Belgium
}

(Received 30 November 2012; accepted 1 April 2013; published online 15 April 2013)

\begin{abstract}
To investigate the cold and hot re-ignition properties of High Intensity Discharge (HID) lamps in more detail an automated setup was designed in such a way that HID lamps of various sizes and under different background pressures can be tested. The HID lamps are ignited with a ramped sinusoidal voltage signal with frequencies between 60 and $220 \mathrm{kHz}$ and with amplitude up to $7.5 \mathrm{kV}$. Some initial results of voltage and current measurements on a commercially available HID lamp during hot and cold re-ignition are presented. (C) 2013 AIP Publishing LLC. [http://dx.doi.org/10.1063/1.4801850]
\end{abstract}

High Intensity Discharge (HID) lamps are attractive as a light source because of their high efficiency and good color rendering properties. ${ }^{1}$ The features that distinguish HID lamps from other gas discharge lamps are their high operating pressure (several bars), small size and high gas temperature (1400-8000 K). HID lamps are used in practical applications where there is a need for high intensity light from a small volume, for example xenon car headlights, stadium lighting, lighting in shops, and other indoor applications., ${ }^{2,3}$ This broad range of use of HID lamps drives the research in the ignition of those lamps, especially in cases where fast and reliable ignition of the lamp is desired.

A conventional metal halide HID lamp contains three substances: starting gas (e.g., argon), buffer gas (e.g., mercury) and a mixture of metal halide salts. The salts are necessary to make the lamp radiate efficiently in the visible part of the spectrum. In a cold lamp the main component in the gas phase is a noble gas at low pressure which determines the ignition or breakdown voltage. ${ }^{3}$ After the lamp has been ignited, the noble gas heats up and the vapor pressures of mercury and metal halide salts start to increase. Due to the addition of the buffer gas and metal halide salts to the gas phase, the pressure inside the lamp will increase to several bars during operation. This as well as the presence of electronegative species in the salts makes breakdown in a hot HID lamp during the first few minutes after switch off much more difficult and complex compared to the cold ignition case.

To increase the reliability of hot re-ignition and avoid the need for a high re-ignition voltage, research is going on to lower this hot re-ignition voltage. ${ }^{2,4,5}$ From previous research on cold HID lamps it is already known that the ignition voltage can be lowered by roughly $50 \%$ if a high frequency $\mathrm{AC}$ voltage is applied instead of a pulsed or DC voltage. ${ }^{6}$ Therefore is decided to implement a high frequency voltage between 60 and $220 \mathrm{kHz}$ in the setup discussed here.

\footnotetext{
a) Author to whom correspondence should be addressed. Electronic mail: a.sobota@tue.nl.
}

Most research on the ignition of HID lamps is concentrated on cold ignition but during hot re-ignition the breakdown conditions will be significantly different. ${ }^{3,7}$ To be able to investigate the hot re-ignition properties of HID lamps under different circumstances a new experimental setup has been designed. The new setup is designed in such way that the breakdown voltage of cold HID lamps and hot HID lamps during cool down can be monitored. In this note the setup will be described in detail together with some initial results on a commercially available metal halide HID lamp.

The experimental setup consists of four main parts (see Figure 1): the vacuum system, the high frequency AC voltage signal generation, measuring the voltage and current, and timing/controlling of the whole system by the home-built software. The connection lines between different devices are given in a schematic overview of the setup in Figure 1. To be able to perform hot re-ignition measurements the system has to be operated in two different modes. First the lamp is burnt in order to heat it up; this is done by connecting a conventional lamp driver to the burner. Afterwards the breakdown experiments are performed during the cool-down phase of the lamp. To switch between the two modes a relay system is implemented (see Figure 1). First relays R1 and R2 are closed while relays R3 and R4 are open. In this mode, the lamp is connected to a driver which heats up the HID lamp. Afterwards relays R3 and R4 are closed which means that the lamp is connected to the high frequency AC voltage pulses while the driver is disconnected. Relay 5 is used as a master switch between both modes.

The vacuum system consists of a $280 \mathrm{~mm}$ long cylindrical glass vacuum vessel (135 $\mathrm{mm}$ in diameter) with a pumping station connected to it. The pressure inside the vacuum vessel can be controlled from atmospheric pressure to $10^{-4}$ mbar. It is made of glass to avoid any influence of large metallic structures close to the HID lamp burner. In the middle of the cylindrical vessel two quartz glass windows are attached opposite to each to be able to perform optical experiments on the lamp burner. On both sides of the vessel stainless steel flanges are placed which can easily be removed. High voltage (HV) 


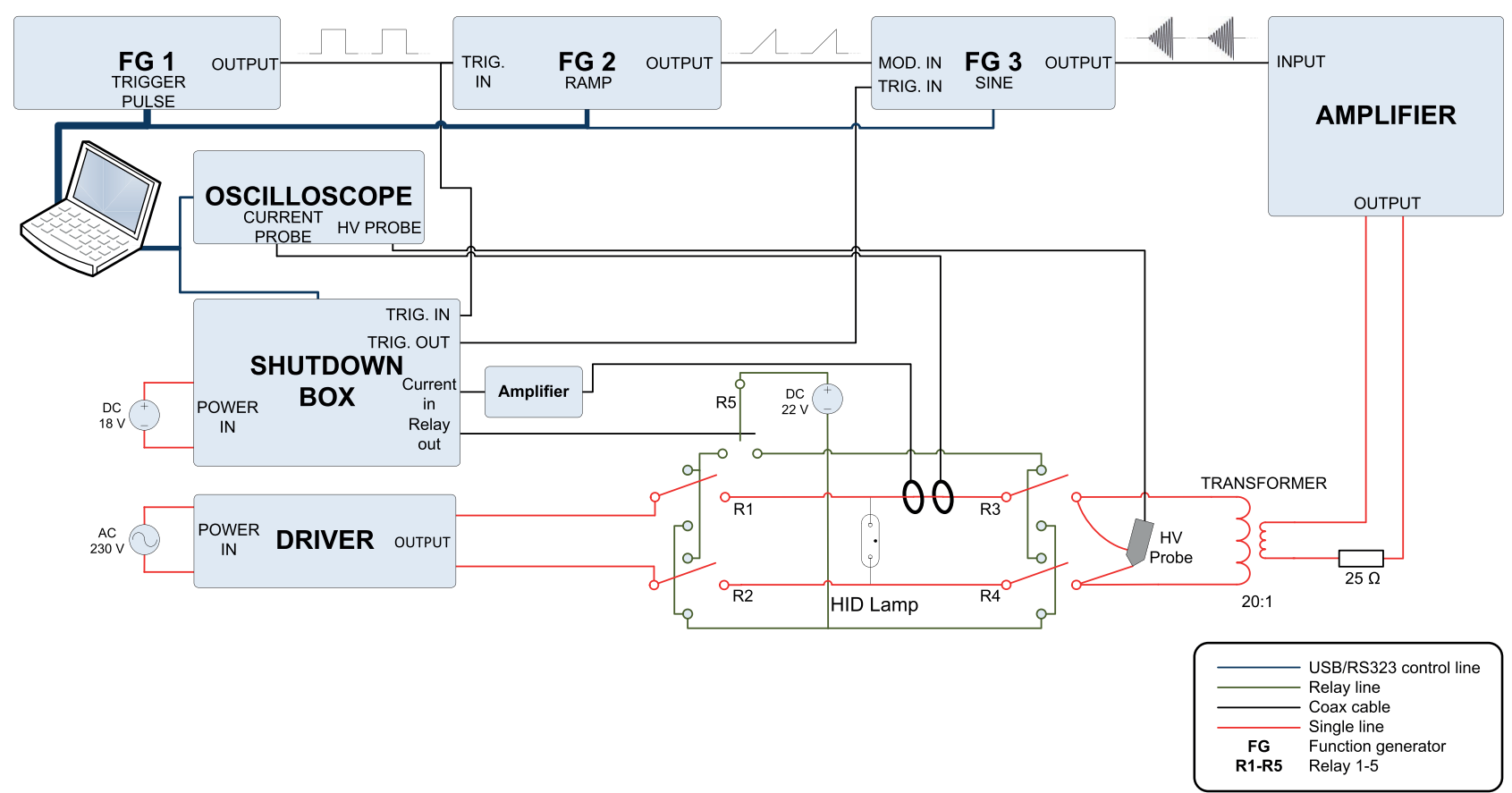

FIG. 1. Schematic overview of the setup for measuring the high frequency AC breakdown voltage of a HID lamp.

feedthroughs and the connection to the vacuum pumping station are mounted on the flanges. The burner of the HID lamp is placed horizontally in the center of the vacuum vessel in line with the grounded electrode. The electrode on which the high frequency $\mathrm{AC}$ voltage is applied passes $4 \mathrm{~cm}$ above the burner. In this configuration the lamp is burnt horizontally.

Built on the base of work published earlier by Beckers et $a l .{ }^{6}$ on high frequency AC breakdown in HID lamps a ramped sinusoidal voltage pulse of frequency $\mathrm{f}_{\text {pulse }}$ between $60 \mathrm{kHz}$ and $220 \mathrm{kHz}$ with a set repetition time, $\mathrm{t}_{\mathrm{rep}}$, of $10 \mathrm{~s}$ is generated in our setup. The repetition time between subsequent voltage pulses is set much longer than the time of the voltage pulse itself $\left(t_{\text {rep }} \gg t_{\text {pulse }}\right)$ to minimize the influence of previous ignition attempts on the breakdown voltage and to still have a reasonable time resolution during a hot re-ignition measurement.

The voltage amplitude increases from 0 to a maximum of $7.5 \mathrm{kV}$ with a slope of $100 \mathrm{~V} / \mathrm{ms}$ or $10 \mathrm{~V} / \mathrm{ms}$ which gives a pulse duration between 75 and $750 \mathrm{~ms}$, respectively. Because of this slowly varying amplitude the timescale of discharge development inside the burner (sub-millisecond) is much slower than the voltage ramping and therefore the voltage amplitude can be considered constant during the breakdown process.

The high frequency $\mathrm{AC}$ voltage signal is generated by three function generators, a high voltage AC amplifier and a transformer (see Figure 1). The first function generator gives a square trigger pulse setting the repetition rate $t_{\text {rep }}$ and pulse width $t_{\text {pulse }}$. The trigger pulse output is connected to the trigger input of the second and third function generator. The second function generator has a saw tooth output and sets the slope of the voltage signal. The third function generator generates a sinus at the given frequency. This sinus is modulated by the output of the second function generator and gated by the first function generator. The maximum voltage amplitude can be varied by varying the amplitude of this sinus signal.

The trigger signal from the first function generator is redirected via the shutdown box. The shutdown box is used to cut off the output signal of the third function generator by cutting of the trigger signal when current is detected. This is necessary because burning the lamp would cause gas heating, which would disrupt the natural cooling curve of the lamp. In addition, the setup was not designed to withstand high current.

After the three function generators the shape of the voltage pulse is generated but the voltage amplitude is in the range of a few volts. The signal is amplified by the high voltage AC amplifier to a few hundred volts. After the HV amplifier the voltage is increased further by a home-made transformer to a maximum voltage of $7.5 \mathrm{kV}$. Between the transformer and the high voltage AC amplifier a $25 \Omega$ resistance is placed to absorb any reflected power.

A typical hot re-ignition experiment consists of two subsequent phases. In the first phase the lamp is burnt until a thermal and chemical equilibrated state inside the HID lamp burner is reached. In the second phase the HID lamp is switched of and the ignition voltage is monitored during the natural cool down of the HID lamp. For each ignition attempt the voltage over and the current through the burner is measured. The voltage is measured with a high voltage probe connected as in Figure 1. The current is measured with a Rogowski coil. Only successful ignition attempts are detected by the oscilloscope and stored. At the moment of breakdown in the burner a drop in voltage and a current peak will be clearly visible. This current peak is used as a trigger for the oscilloscope.

To have an appropriate timing and data processing throughout the experiment, the system is automated with the automating software LabVIEW ${ }^{\mathrm{TM}}$. The main tasks of the 


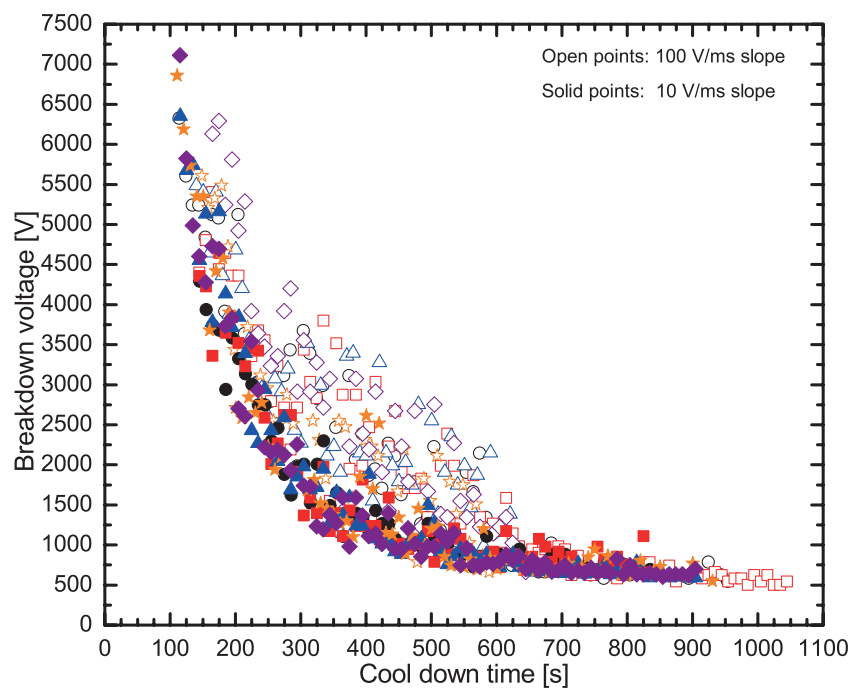

FIG. 2. Hot re-ignition voltage during cool down of a HID lamp burner with two different voltage pulse slopes at $100 \mathrm{kHz}$.

software are to configure all function generators and oscilloscope to the specified measuring frequency and slope, control of the relay switching, and collect and save all data from the oscilloscope for every breakdown event while keeping track of the cool down time. The cool down time is defined as the time that has elapsed after the lamp has been switched off.

The system was tested by measuring the breakdown voltage of a commercially available HID lamp. The burner inside this HID lamp is made from translucent poly crystalline alumina (PCA) and two rod shaped tungsten electrodes with an inter electrode distance of $7.15 \mathrm{~mm}$. The gas inside the burner consists of argon with trace amounts of mercury when the lamp is cold (room temperature). When the lamp is hot, all mercury and a part of the metal halide salts will still be evaporated contributing to a different, much higher, breakdown voltage.

In Figure 2, a typical result of a high frequency breakdown voltage measurement during cool down of a HID lamp is shown. In this specific example the pulse frequency was set to $100 \mathrm{kHz}$. The graph shows the breakdown voltage during 5 cool down curves for two different slopes of the applied voltage pulse: $100 \mathrm{~V} / \mathrm{ms}$ and $10 \mathrm{~V} / \mathrm{ms}$. Before each cool down curve the lamp has been burnt for $15 \mathrm{~min}$ to reach an equilibrium composition and a wall temperature of approximately $1500 \mathrm{~K}$ (as measured with a pyrometer).

There are a few remarks that can be made from the graph shown in Figure 2. First, the 5 cool down curves show good overlap with each other for both slopes. This shows that the breakdown voltage as measured with the setup gives a reproducible result. Second, during the first $100 \mathrm{~s}$ after shut down of the lamp no successful ignition attempt occurred. The reason for this is that directly after switch off, the vapor pressure of mainly mercury inside the burner is still high and halide species can easily attach free electrons necessary for successful breakdown. As a result the breakdown voltage in this region is above the $7.5 \mathrm{kV}$ limit of our setup. During cool down the pressure and vapor pressures of the metal halides drop as the temperature of the burner decreases and species start to condense. This causes the breakdown voltage to decrease significantly in the first $600 \mathrm{~s}$ after switch off. The relative importance of pressure and change in composition on the high frequency $\mathrm{AC}$ breakdown voltage is still under investigation. The last aspect to remark here is the difference in scatter in the breakdown voltage for the two different slopes especially for cool down times of less than $600 \mathrm{~s}$. This indicates that there is a significant delay between the moment when the minimum required breakdown voltage is applied and the moment of breakdown. This is the statistical time lag which is inherent for all breakdown processes. For the same statistical time lag the voltage will rise more with a steeper slope resulting in more scatter in the breakdown voltage as can be seen in Figure 2.

In conclusion, a setup has been designed for measuring the high frequency $\mathrm{AC}$ breakdown voltage of cold and hot HID lamps during cool down. The system is designed to deliver high frequency $(60-220 \mathrm{kHz})$ voltage pulses up to $7.5 \mathrm{kV}$ in amplitude to an arbitrary shaped HID lamp burner. The setup is automated in order to measure the breakdown voltage during cool down of a HID lamp with accurate timing of the cool down time. The pressure and gas composition surrounding the burner can be varied easily which makes the setup suitable for testing the high frequency breakdown voltage for a broad range of applications. The first results on a commercial metal halide HID lamp show that having breakdown in a hot HID lamp requires much higher voltage than in a cold lamp. This is mainly caused by the high vapor pressure of mercury and metal halide salts.

This work is financially supported by the CATRENE SEEL (Solutions for Energy Efficient Lighting) project (CA502).

${ }^{1}$ P. Flesch, Light and Light Sources (Springer-Verlag, Berlin, 2006).

${ }^{2}$ W. W. Byszewski, Y. M. Li, A. B. Budinger, and P. D. Gregor, Plasma Sources Sci. Technol. 5, 720 (1996).

${ }^{3}$ G. G. Lister, J. E. Lawler, W. P. Lapatovich, and V. A. Godyak, Rev. Mod. Phys. 76, 541 (2004).

${ }^{4}$ B. Lay, R. S. Moss, S. Rauf, and M. J. Kushner, Plasma Sources Sci. Technol. 12, 8 (2003).

${ }^{5}$ M. Czichy, T. Hartmann, J. Mentel, and P. Awakowicz, J. Phys. D 41, 144027 (2008).

${ }^{6}$ J. Beckers, F. Manders, P. C. H. Aben, W. W. Stoffels, and M. Haverlag, J. Phys. D 41, 144028 (2008).

${ }^{7}$ A. Sobota, J. H. M. Kanters, F. Manders, M. F. Gendre, J. Hendriks, E. M. van Veldhuizen, and M. Haverlag, J. Phys. D 44, 224002 (2011). 